\title{
A Correlational Analysis of Public Procurement Policy and Utilisation of Public Funds for Service Delivery in Ondo State (2007-2013)
}

\author{
Kunle Sehinde Benson ${ }^{1}$, Olumide Olusesan Asere ${ }^{1} \&$ Kazeem Oyedele Lamidi ${ }^{2}$ \\ ${ }^{1}$ Department of Public Administration, Faculty of Administration, Obafemi Awolowo University, Ile-Ife, Nigeria \\ ${ }^{2}$ Department of Local Government Studies, Faculty of Administration, Obafemi Awolowo University, Ile-Ife, \\ Nigeria \\ Correspondence: Kunle Sehinde Benson, Department of Public Administration, Faculty of Administration, \\ Obafemi Awolowo University, Ile-Ife, Nigeria. E-mail: benjolad@gmail.com
}

Received: July 11, 2016 Accepted: July 28, 2016 Online Published: April 27, 2017

doi:10.5539/par.v6n1p31 URL: http://dx.doi.org/10.5539/par.v6n1p31

\begin{abstract}
This paper investigated public procurement policy vis-à-vis effective and efficient utilization of public fund for service delivery using Ondo State as a case study. Primary and secondary data were utilised for this study. The study universe 1,422 respondents comprised senior officials from selected service delivery ministries, agencies and civil society groups. 284 respondents were selected from sample groups using stratified sampling technique with a sample fraction of $20 \%$. Interviews were conducted to complement the data gathered through questionnaire administration. The results showed that there is about thirty three percent (33\%) positive relationship between the application of procurement policy and effective and efficient utilization of public fund for service delivery in Ondo State $(\mathrm{r}=+0.332, \mathrm{p}<0.01)$. This paper concluded that public procurement policy had a minor influence on effective and efficient utilization of public fund for service delivery in Ondo State.
\end{abstract}

Keywords: public procurement, policy, public fund, governance and service delivery

\section{Introduction}

Public procurement is a concept that is traditionally associated with purchasing and supply of goods and services. Studies of contemporary literature in public administration have shown however a paradigm shift from being viewed purely as concerned with the acquisition of goods and services to reflect a whole spectrum of good governance practices (Arrowsmith, Linarelli \&Wallace, 2000), nevertheless, the end results of this process gear towards achieving service delivery. Also, the quantum of resources currently expended on procurement annually both in the developed and developing world has increased the growing concern for the proper management of these resources in facilitating service delivery (McCrudden, 2007).

The problem of corruption was noted as a key rationale behind the implementation of the new public procurement policy in Nigeria. Obasanjo (2003) corroborated this when he asserted that until 1999, Nigeria

... had practically institutionalized corruption as the foundation of governance. Hence institutions of society easily decayed to unprecedented proportions as opportunities were privatized by the powerful.

Arising from the foregoing, the public sector was in crisis by 1999 and in need of desperate solutions. The introduction of the new public procurement policy through the enactment of the Public Procurement Act, 2007 consequently emerged amidst staggering inequalities, inefficiency, delays in project execution, high cost of contract and lack of professionalism and other institutional maladies, all of which have made existing procurement process unwieldy and dysfunctional (Olatunji, 2008). In Ondo State, the implementation of due Process and procurement reforms in most Government establishments have yielded into cynicism as to whether it has been characterised by undue influence and favouritism. It is in connection to the above that this paper examines the correlational relationship between the public procurement policy and service delivery in Ondo state between 2007 and 2013.

\section{Literature Review}

Definitional issues have generated a lot of discus among scholars in the field of public procurement. The subject is 
viewed by many as involving acquisition by contract, usually with appropriated funds, supplies, services, and interests in real property by and for the use of the Federal Government. The acquisition could be achieved through purchase or lease, whether the supplies, services, or interests are already in existence or must be created, developed, demonstrated, and evaluated.(Nash, Cibnic, Ralph and Nagle, 2006).The United Nations viewed public procurement as an "overall process of acquiring goods, civil works and services including all functions from the identification of needs, selection (World Bank, 2007). and solicitation of sources, preparation and award of contract, and all phases of contract administration. (See, http://sate.gr/nea/international\%20handbook\%20of\%20Public\%20Procurement.pdf)

Procurement process is the heart of a sound procurement system (Fayomi, 2013). Public procurement according to him also involves more than the procurement process alone" and it should not only consist of supporting, but also "important components" including strategy and policy of the organization, methods and procedures, personnel organization and information. In another approach towards the definition of public procurement, McCue and Gianakis (2001) have provided more insight into the breadth and scope of Public Procurement through the work of procurement professional which often includes handling procurement request and soliciting and evaluating bids and supplier analysis. Pegnato (2008) viewed public procurement as a business process within a given political system, with distinct consideration of integrity, accountability, national interest and effectiveness. These business operations of government, as controlled by public procurement, usually affect many different elements of society (Olatunji, 2008). The procuring entities for instance have needs for material support like roads and hospitals to help in fulfilling their designated national mission. The business communities of actual or potential suppliers on the other hand need to satisfy government procurement requirement.

Public procurement plays an important role in the management of public fund and this is further buttressed by the position of prominent scholars like, Thai, (2008) who expanded the scope and components of public procurement policy to include; four major economic activities such as (a) providing the legal framework for all economic activities, (b) redistributing income through taxation and spending; (c) making public goods and services freely available to the public such as national defence, public safety, education, and infrastructure (bridges and roads); and (d) purchasing goods, services and capital asset. Guttman (2013) asserted that the world of public procurement is becoming more than just getting the "plumbing and wiring" right. Indeed, the role and application of public procurement policies and practices is an essential element of design and implementation with crucial consequences for the quality of outcome. Anderson, Robert and Williams (2009) equally reiterated that governments all over the world use public procurement policy and implementation mechanism to address a number of issues including budget implementation, service delivery and general developmental concerns.

In spite of its relevance, public procurement has largely been a neglected area of academic education and research, but policy makers and public procurement professionals have paid great attention to procurement improvements and reforms (Thai, 2008). He advanced that efficient and effective public procurement systems have influence on the provision of government services such as roads, hospitals, healthcare, sanitation, telecommunication facilities, education, environmental protection, promotion of human rights. It is because of its importance to the well-functioning of the public sector that public procurement systems in Africa were subjected to reforms so as to create a well-functioning public procurement system (http://sate.gr/nea/international\%20handbook\%20Public\%20Procurement.pdf.)

At the beginning, procurement focused more on legal arrangements and law reforms. More recently, it has focused on the management aspects of procurement and the tendency is to reinforce procurement as a business process within government (EURODAD, 2009). The selection here focuses on the points of view most relevant to the question of procurement and development from the perspective of aid agencies, donors and the International Financial Institutions (IFI) (Basheka, 2008).

Another perspective deals with the functions of the practitioners. It is a fact that procurement officials spend most of their time on the following major tasks; handling procurement requests, soliciting and evaluating bids and proposals, supplier analysis, negotiating, and contract award and administration (MCcue, 2003). This could be termed as a functional approach to the definition of public procurement. The National Institute of Government Purchasing (NIGP) in 2003, as reported by Scott, 2004, also conceptualised procurement to mean; purchasing, leasing or otherwise, acquiring any supplies, services or construction. It includes all functions that pertain to the acquisition of, description of requirement, selection and solicitation of resources, preparation and award of contract and all phases of contract administration (Wright, 2016). It equally combines functions of purchasing, inventory control, traffic and transportation, receiving inspection, store keeping and salvage and disposal operation (Wright, 2016). Perhaps this may have reinforced the decision of the American government to replace "procurement" with "acquisition". 
MCcue (2003) quoting, the congress (2003), defined procurement as including all stages of the process of acquiring property or services beginning with the process for determining the need for property or services and ending with contract completion and closeout. In the same year, the Congress passed another law called the Services Acquisition Reform Act (SARA) which indicated that Acquisition is the process of acquiring with appropriated funds by contract for purchase or lease of property or services that support the mission and goals of an executive agency (Scott, 2004). The process starts from the point at which the requirement of the executive agency is conceptualised to the actual acquisition with appropriated fund property or services that are in existence or must be created, developed, demonstrated and evaluated. The intention of Congress by the new expansive definition is to view the buying process from a broader perspective, encompassing technical and management functions and to remove ambiguities from the interpretation of this definition (MCcue, 2003).

Institutional support for public procurement is strongly advocated by the World Bank which has developed a framework of procurement assessment under its "Country Procurement Assessment Review" (CPAR). This framework consists of four elements: legal framework, institutional framework and capacity, procurement operations and practice, and integrity of the procurement system (Fayomi, 2013). In terms of organization, public procurement is dictated by the government system. In general, there are two major government systems: unitary and federal. In a unitary system, the central government exercises various levels of control over local governments in various countries, be it provincial or local governments. Local government procurement structure and process are dictated by the national government (http://sate.gr/nea/international\%20handbook\%20Public\%20Procurement.pdf.).

Public procurement has recently taken the centre stage in discussions on development because of its pivotal role in the overall development of the national economy of many states thus further strengthening the utilitarian value of the subject (EURODAD, 2009). This may have accounted for the consensus among scholars on the strategic role of public procurement as a policy tool.

To establish the relationship between public procurement and policy, Macrudden (2007), Anderson and Kovacic (2009) defined policy developments as involving the challenges that occur in ensuring effective competition in public procurement market. They identified two principal public policy tools through which competition can be maintained and enhanced in public procurement markets as international trade liberalisation and competition policy. While the article draws particularly on policy developments and experience in the United States and (to a lesser extent) Europe, an effort is made to illustrate the universality of the issues raised and their significance for developing and developed countries.

Macrudden (2007) further asserted that the various provisions of the agreement relating to the provision of information to potential suppliers, contract awards, pre-qualification of suppliers and other elements of the procurement process are intended to ensure transparent and non-discriminatory conditions of competition between suppliers, including domestic and foreign suppliers. The need for such a framework of rules to ensure competition derives from the potentially overwhelming pressures that most governments face to limit competition and use procurement processes to benefit particular suppliers.

Governance is how those who have power use it in the management of public affairs. In terms of the public sector, the term "governance" is synonymous to "government." Governments are established for a purpose (http://sate.gr/nea/international\%20handbook\%20Public\%20Procurement.pdf.). Inherently, government or public sector is established to provide public services to citizens of a particular country. The sector is arranged under organizational units, each with specialized constitutional and administrative roles (Olatunji, 2008). To perform the specialized roles and responsibilities, such units require resources (financial, material, and human), and these resources have to be acquired through a process of procurement. The public sector has three branches, namely; the legislative branch, often called the national assembly or parliament, the judiciary, which is the system of courts, and the executive that implements government policies (http://sate.gr/nea/international\%20handbook\%20Public\%20Procurement.pdf.). The operation of these units must be properly aligned and rationalized to provide effective governance and tackle problems of poverty (Basheka, 2008).

There is a nexus between public procurement policy and public fund management, public administration and its fundamental principles and practices are framed around transparency, accountability, and cost economy (Dibie, 2004).To further strengthen this connection is the argument that through globalization, localization, and information revolution. Citizens have been empowered to demand accountability from their governments, for it is accountability that provides a mechanism for measuring governments' performance (Shah, 2005). The challenge for decision makers in Africa has been to structurally and institutionally transform the state and the 
government to become legitimate and relevant to the masses (Kalu, 2004).

To achieve this end, Basheka (2008) further expatiated that good governance is measured around four key pillars: accountability, transparency, predictability, and participation, and these are cognisance factors on public procurement policy and processes in the developing world. None of the four pillars and their constituent components can stand alone without the other because the public sector operates like a system. A mistake or weakness in one part of the public sector is felt by other components of the public sector. This postulation justifies the need for administrators and academics to focus on this field of study to enhance institutional and process improvement in the public service delivery.

McCrudden (2007) analyzed how governments in developed and developing countries use their contracting power in order to advance social equality and reduce discrimination. He argues that this approach is an entirely legitimate and efficient means of achieving social justice. It also examines the impact of international and regional regulation of the national economy, and questions the extent to which the issue of procurement policy can be regulated at the National, European or International levels (EURODAD, 2009). Arrowsmith and Kunzlik (2009) asserted that governments are often concerned not only with value for money but also with promoting their social and environmental objectives. However, imposing social and environmental requirements makes it harder for some suppliers to participate in public procurement. EC laws thus limit the ability of national governments to implement such policies.

Policy is a guiding tool of any organisation. However, public procurement policy shares similar character as an institutional device for public expenditure control. Thai (2008) defined institutions as invisible because they are "fundamentally shared concepts," they exist in minds of the participants," and "sometimes are shared as implicit knowledge rather than in an explicit and written form" (Ostrom 1999). It must be institutionalized to be functional. It therefore behoves on nations to give credence to their social and economic practices by taking steps to reform their processes and enacting laws that would guarantee accountability, transparency and competition which are the three key pillars of a successful public expenditure management.

Ware, Shaun and Edgardo (2007) have argued that the literature on procurement reform is increasingly concerned with other governance aspects of procurement that may affect its effectiveness and impact, including organizational arrangements, recommendations on process management and professionalization of procurement officials. However, EURODAD (2009) maintained that this is mainly technical and "efficiency" driven literature. Effective governance of the public sector is at the centre of many pressing challenges confronting both developed and developing countries.

Service delivery entails a well-functioning public sector, which is thought to be responsive to the citizenry and to be reasonably efficient in the delivery of public services. A well-functioning public sector also involves the following; transparency and predictability of its decision-making processes and oversight mechanisms (checks and balances) to guard against arbitrariness and to ensure accountability in the use of public resources (Akpan-Obong, 2010). However, these oversight mechanisms do not eliminate the flexibility and delegation needed to respond quickly to changing circumstances (World Bank, 2007).

Good governance is measured around four key pillars: accountability, transparency, predictability, and participation, and has taken a centre stage in any discussion on sustainable development in the developing world (http://sate.gr/nea/international\%20handbook\%20Public\%20Procurement.pdf). Thai (2007) further argued that, efficient and effective public procurement policy have influence on the provision of basic social amenities and services.

On the question of how development policies can best be promoted, the literature on governance (particularly on transparency and anti-corruption) should be taken into account. In particular, there is agreement that corruption affects development directly by diverting funds from projects and activities intended for public benefit into the private pockets of corrupt people (EURODAD, 2009). Also noted, is that governance problems usually hinder the effectiveness of otherwise well-meant and well-designed policies, including policies to use procurement for development. This is particularly true as public contracting (or procurement) which is particularly sensitive to corruption and easily subject to abuse. In addition, many critiques of the use of procurement as a development tool start from the premise of its vulnerability to abuse.

The above probably reinforced the views held by Kalu (2004) who asserted that, the African public sector has been grappling with poverty and provision of effective services. Tackling the poverty challenge is the responsibility of the public sector in collaboration with other stakeholders (http://sate.gr/nea/international\%20handbook\%20Public\%20Procurement.pdf). However, the state will deliver more effectively to all citizens and the poor in particular if certain mechanisms are in place to man the running of 
government operations and check abuses such as public procurement policy. This paper therefore sought to fill this missing gap in literature by cross-examining the potentials of public procurement vis-à-vis its effect on service delivery, using Ondo state, southwestern Nigeria as a case study.

\section{Hypothesis}

This hypothesis would be tested so as to provide a research direction for this study:

$\mathbf{H}_{\mathbf{0}}$ : Application of procurement policy does not significantly influence effective and efficient utilization of public fund for service delivery in Ondo State.

\section{Methodology}

This paper utilized primary and secondary sources of data collection. The justification of this time frame (2007 2013 ) is that the public procurement Act was enacted and incorporated into Ondo state civil service in 2007; it thus appears to be matured for evaluation by the year 2013. The primary data were collected through administration of questionnaire and conduct of in-depth interviews. Purposive sampling technique was employed to select three ministries namely: Ministries of Agriculture, Budget and Planning, and Education; and one Agency which is the Price and Project Monitoring Unit (PPMU) Ondo state. The choice of the ministries and the agency was based on their level of involvement in and the size of their procurement activities.

The total study population comprised Agriculture (250), Budget and Planning (102), Education (400), PPMU (70), Registered contractors (250) and Civil Society Groups (350) representing end users of government procurement, totalling 1,422 respondents in all. Two hundred and eighty-four respondents were selected using stratified sampling technique for questionnaire administration with a sample fraction of $20 \%$, using the ministries and the agency for stratification. Stratified sampling technique was used to select workers on Grade Levels 07 and above - these are senior officers in the selected service delivery ministries and agencies and they are directly involved in the implementation process of public procurement policy.

In addition, interviews were conducted to elicit information from three Permanent Secretaries, three Directors and three Deputy Directors in each of the selected ministries and agency as well as two Directors from the State Tenders Board (totalling 11), to complement information collected through the questionnaire. Secondary data were obtained from academic journals, official documents such as Annual Budget Performance Report of Ondo State. Data collected were analyzed using appropriate frequency, percentage, mean value, standard deviation and spearman correlation co-efficient.

\section{Discussion of Findings}

This part of the paper provides a discussion of findings on the subject matter. It expressed the respondents' opinions on the influence of public procurement policy on service delivery within the study area. As shown in Table 1, out of the eleven influences considered, nine points agreed and two disagreed on the various influence public procurement policy has made on service delivery in the Ondo State. Items 2, 3, 5, 6, 7, 8, 9, 10 , and 11 agreed while items $1 \& 4$ were disagreed. The items where we have collective agreement had weighted average score values of 2.86, 2.54, 3.15, 2.73, 2.50, 2.56, 2.94, 2.58, 2.58 and items with cumulative disagreement had weighted mean score of 2.47 and 2.49 however, the t-values for items 2, 3, 5, 7, 8, 10 and 11 were significant even at $\mathrm{p}<0.01$ which implies that although there are average agreements and disagreements, the proportions of the respondents that complied are not significantly different from those that does not. In other words, there were conflicting opinions concerning these issues. So, we cannot say vividly that "procurement policy eliminates fraud and inefficiency (item 1); closes the economic space to a greater number of participant (item 3); brought with it good management of public money and assets (item 5); has not significantly improved skill and professionalism in the public service (item 7); significantly reduced corrupt practices among public officials (item 8); has not enhanced the use of technology especially ICT in policy project implementation (item 10); and prevents equal access to bidding opportunities (item 11) in Ondo state" or not. These conflicting opinions are distributed in equal amount across sampled practitioners (details in Table 1).

First, influence of procurement policy with respect to elimination of inefficiency and fraud in Ondo state was considered. The result of the opinion poll showed that public procurement policy has not been able to eliminate fraud and inefficiency in Ondo State civil service delivery. This assertion was supported by one hundred and twelve respondents (46\%) agreement and forty five (54\%) disagreement. Although this result was very close, it was not significant enough to finally conclude that procurement policy does not eliminates fraud and inefficiency; however, its weighted mean score (2.47) and t-value (0.800) revealed average disagreement and insignificant difference between those that agree and disagree.

For items that were cumulatively agreed, this agreement was supported by weighted means score and significant 
(t-values) of 2.86 (7.971), 3.15 (12.975), 2.94 (8.627), and 2.73 (4.889) with standard deviations of 0.701, 0.786, 0.798 , and 0.751 for items $2,5,9$ and 6 respectively. The respondents clearly agreed that public procurement policy discourages waste and abuse of public office; establishes pricing standards and benchmarks; set approved guidelines and regulations for contracts; and eradicates white elephant projects and increases execution of projects that have social and economic value in Ondo State while items in item 1 and 4 were disagreed.

This findings are corroborated by a paper presented at a three day Training on Procurement Reforms for officials in charge of Procurement in Ondo State, by the former Ondo State PPMU coordinator, Iji I. entitled: "Public Procurement in Nigeria: The Imperative of Reform". The facilitator analysed the benchmark prices set by the unit in the past three and half years. According to him about N41.5 billion was made as total saving in Ondo State. Such savings amongst others include the following:

(1) \#7.5 billion was saved on road contracts such Okitipupa/Igbokoda to Aiyetoro.

(2) \#423 million was saved in the supply of Drugs and other Hospital Equipments in Hospital Management Board Contracts,

(3) \#440.8 million was saved from Water Corporation Projects,

(4) \#450.1 million was saved in the procurement of Earth Moving Equipments in the Ministry of Works.

(5) \#4 6.2 million was saved in the renovation and refurbishment of the State House of Assembly contracts.

(6) Every computer of highest configuration series now goes for \#240,000 as against \#320,000 before.

(7) Sharp Photocopying Machine (5F 1118) Model now goes for\#234, 000as against N450, 000 before.

(8) National Room Unit Air conditioners (1.5HP) can only be purchased for \#63, 350 now instead of \#95, 500 previously.

(9) Sharp 20" Coloured Television Set can only be obtained for \#25,000 as against \#34, 500 previously.

(10) Thermo-cool T170 Refrigerator now goes for N48, 500 as against $\# 98,800$.

Summarily, public procurement policy implementation has brought with it a host of other positive development to Ondo State in terms of good management of public fund as indicated below;.

(a) Good governance of public money and assets resulting in the reduction of corruption. Whether we like it or not governance shrouded in secrecy cannot be termed good in any form of ramification.

(b) Improved systems plan and project preparation leading to accuracy of costing, cost/benefit analysis and prioritization in deciding the spending pattern and plan for any given year. Example of this is the well thought out Roadmap to Progress which is a result of a high level consultation/ brain stormy sessions of a due process.

(c) More optimal resource allocation decisions to achieve clearly articulated public policy objectives through enhanced identification of the costs and benefits of alternative expenditure decisions. 
Table 1. Assessment of the influence of the application of due process and public procurement in Ondo State State civil Service

\begin{tabular}{|c|c|c|c|c|c|c|c|c|c|c|c|}
\hline $\mathbf{S} / \mathbf{N}$ & Item & Option & $\begin{array}{l}\text { SD } \\
\text { (1) }\end{array}$ & $\begin{array}{l}\text { D } \\
(2)\end{array}$ & $\begin{array}{l}\text { A } \\
\text { (3) }\end{array}$ & $\begin{array}{l}\text { SA } \\
\text { (4) }\end{array}$ & $\begin{array}{l}\text { Sum } \\
\text { score }\end{array}$ & $\begin{array}{l}\text { Weighted } \\
\text { average } \\
\text { score }\end{array}$ & $\begin{array}{l}\text { Std. } \\
\text { Dev. }\end{array}$ & T-test & $\mathbf{R}$ \\
\hline 1 & $\begin{array}{l}\text { Procurement policy eliminates fraud } \\
\text { and inefficiency in Ondo state }\end{array}$ & $\begin{array}{l}\text { Freq. } \\
\%\end{array}$ & $\begin{array}{l}30 \\
12.2\end{array}$ & $\begin{array}{l}104 \\
42.3\end{array}$ & $\begin{array}{l}76 \\
30.9\end{array}$ & $\begin{array}{l}36 \\
14.6\end{array}$ & 610 & 2.47 & .888 & .800 & $\mathrm{D}$ \\
\hline 2 & $\begin{array}{l}\text { Discourages waste and abuse of public } \\
\text { office in Ondo state }\end{array}$ & $\begin{array}{l}\text { Freq. } \\
\%\end{array}$ & $\begin{array}{l}10 \\
4.1\end{array}$ & $\begin{array}{l}50 \\
20.4\end{array}$ & $\begin{array}{l}150 \\
61.3\end{array}$ & $\begin{array}{l}35 \\
14.3\end{array}$ & 700 & 2.86 & 701 & 7.971 & A \\
\hline 3 & $\begin{array}{l}\text { Closes the economic space to a greater } \\
\text { number of participant in Ondo state }\end{array}$ & $\begin{array}{l}\text { Freq. } \\
\%\end{array}$ & $\begin{array}{l}28 \\
11.4\end{array}$ & $\begin{array}{l}83 \\
33.9\end{array}$ & $\begin{array}{l}108 \\
44.1\end{array}$ & $\begin{array}{l}26 \\
10.6\end{array}$ & 622 & 2.54 & .832 & .730 & A \\
\hline 4 & $\begin{array}{l}\text { Brought with it good management of } \\
\text { public money and assets }\end{array}$ & $\begin{array}{l}\text { Freq. } \\
\%\end{array}$ & $\begin{array}{l}44 \\
18.0\end{array}$ & $\begin{array}{l}60 \\
24.5\end{array}$ & $\begin{array}{l}118 \\
48.2\end{array}$ & $\begin{array}{l}23 \\
9.4\end{array}$ & 610 & 2.49 & 894 & -.179 & $\mathrm{D}$ \\
\hline 5 & $\begin{array}{l}\text { Establishes pricing standards and } \\
\text { benchmarks }\end{array}$ & $\begin{array}{l}\text { Freq. } \\
\%\end{array}$ & $\begin{array}{l}13 \\
5.3\end{array}$ & $\begin{array}{l}21 \\
8.5\end{array}$ & $\begin{array}{l}128 \\
52.0\end{array}$ & $\begin{array}{l}84 \\
34.1\end{array}$ & 775 & 3.15 & .786 & 12.975 & A \\
\hline 6 & $\begin{array}{l}\text { Eradicates white elephant projects and } \\
\text { increases execution of projects that } \\
\text { have social and economic value }\end{array}$ & $\begin{array}{l}\text { Freq. } \\
\%\end{array}$ & $\begin{array}{l}14 \\
5.7\end{array}$ & $\begin{array}{l}68 \\
27.8\end{array}$ & $\begin{array}{l}132 \\
56.9\end{array}$ & $\begin{array}{l}31 \\
12.7\end{array}$ & 670 & 2.73 & .751 & 4.889 & A \\
\hline 7 & $\begin{array}{l}\text { Has not significantly improved skill } \\
\text { and professionalism in the public } \\
\text { service }\end{array}$ & $\begin{array}{l}\text { Freq. } \\
\%\end{array}$ & $\begin{array}{l}31 \\
12.6\end{array}$ & $\begin{array}{l}88 \\
35.8\end{array}$ & $\begin{array}{l}99 \\
40.2\end{array}$ & $\begin{array}{l}28 \\
11.4\end{array}$ & 616 & 2.50 & .856 & .074 & A \\
\hline 8 & $\begin{array}{l}\text { Significantly reduced corrupt practices } \\
\text { among public officials in Ondo state }\end{array}$ & $\begin{array}{l}\text { Freq. } \\
\%\end{array}$ & $\begin{array}{l}30 \\
12.2\end{array}$ & $\begin{array}{l}84 \\
34.1\end{array}$ & $\begin{array}{l}96 \\
39.0\end{array}$ & $\begin{array}{l}36 \\
14.6\end{array}$ & 630 & 2.56 & .887 & 1.079 & A \\
\hline 9 & $\begin{array}{l}\text { Set approved guidelines and } \\
\text { regulations for contracts in Ondo State }\end{array}$ & $\begin{array}{l}\text { Freq. } \\
\%\end{array}$ & $\begin{array}{l}18 \\
7.3\end{array}$ & $\begin{array}{l}32 \\
13.0\end{array}$ & $\begin{array}{l}143 \\
58.1\end{array}$ & $\begin{array}{l}53 \\
21.5\end{array}$ & 723 & 2.94 & .798 & 8.627 & A \\
\hline 10 & $\begin{array}{l}\text { Has not enhanced the use of technology } \\
\text { especially ICT in policy project } \\
\text { implementation in Ondo State }\end{array}$ & $\begin{array}{l}\text { Freq. } \\
\%\end{array}$ & $\begin{array}{l}27 \\
11.2\end{array}$ & $\begin{array}{l}73 \\
30.3\end{array}$ & $\begin{array}{l}114 \\
47.3\end{array}$ & $\begin{array}{l}27 \\
11.2\end{array}$ & 623 & 2.58 & .833 & 1.585 & A \\
\hline 11 & $\begin{array}{l}\text { Prevents equal access to bidding } \\
\text { opportunities in Ondo State }\end{array}$ & $\begin{array}{l}\text { Freq. } \\
\%\end{array}$ & $\begin{array}{l}30 \\
12.4\end{array}$ & $\begin{array}{l}65 \\
57.0\end{array}$ & $\begin{array}{l}122 \\
50.6\end{array}$ & $\begin{array}{l}24 \\
10.0\end{array}$ & 622 & 2.58 & .833 & 1.507 & A \\
\hline
\end{tabular}

Source: Authors, 2014.

\section{Testing of Hypothesis}

$\mathbf{H}_{\mathbf{0}}$ : Application of due process and procurement policy does not significantly influence effective and efficient utilization of public fund for service delivery in Ondo State

According to Table 2, the spearman's correlation coefficient was positive $(+0.332)$ and significant at $p<0.01$. The positive coefficient indicated that there is thirty three percent $(33 \%)$ positive relationship between the application of due process and effective and efficient utilization of public fund for service delivery in Ondo State. We can therefore reject the null hypothesis and conclude that application of due process and procurement policy is significantly associated with effective and efficient utilization of public fund for service delivery and that a quarter of the changes occurring in utilization of public fund is associated with the application of due process. The positive relationship also showed that the higher the due process, the better the efficiency of procurement policy delivery in the public service. 
Table 2. Correlation analysis between due process and procurement policy and the efficient utilization of Public funds in Ondo state civil service

\begin{tabular}{lllr}
\hline \multicolumn{2}{c}{ Correlations } & \multicolumn{1}{c}{$\begin{array}{c}\text { Application of due process and } \\
\text { procurement policy }\end{array}$} \\
\hline \multirow{2}{*}{$\begin{array}{l}\text { Effective and efficient utilization of public } \\
\text { fund for service delivery }\end{array}$} & $\begin{array}{l}\text { Spearman's Correlation } \\
\text { Coefficient }\end{array}$ & $.332^{* *}$ \\
\cline { 2 - 3 } & Sig. (2-tailed) & .000 \\
\cline { 2 - 3 } & $\mathrm{N}$ & 282 \\
\hline
\end{tabular}

** Significant at $\mathrm{p}<0.01$.

Source: Authors, 2014

\section{Content Analysis of the In-Depth Interviews}

All the interviewed key officers agreed that the Ondo State public procurement policy has impacted positively on the standard of living of the people of the state. They went further to mention numerous people oriented projects such as Mother and Child Hospital popularly known as Iya Abiye hospitals, the Mega- Primary Schools, construction of standard modern market; and the beautification of the cities particularly, Akure and other cities in other senatorial zones. All the key officers were of the opinion that project implementation in Ondo State conforms to the needs and expectation of the end users.

They went further to explain that the state has Ministry of Community Development that usually carries out opinion poll on the priority of the people to determine the top needs and expectations of the people and that the outcomes of such undertaking that usually determine the projects government embarks on. Secondly, they said that, Ondo state governor presented himself for re-election and he was voted for and returned. This means he has met the needs and expectations of the people. The key officers agreed that procurement policy has minimized the incidence of corrupt practices in the award and management of public project.

They however opined that, if PPMU were not to be in place, the incidence of corruption would have been very high in the award of and management of public projects. Majority of them agreed that PPMU does check corruption to some extent but not hundred per cent and that there are loopholes which are not peculiar to Ondo state, Nigeria and that even the advanced countries. The efficiency of the Western systems however helps to check corruption and punish corrupt people than Nigeria.

\section{Concluding Remarks}

The study concluded that public procurement policy had, but not strongly, influenced effective and efficient utilization of public fund for service delivery in Ondo State; however the inherent challenges facing public procurement had led to pseudo implementation of the policy with grievous consequences of poor implementation and corrupt practices in public procurement of Ondo State. Considering the findings of this study, therefore, it could be remarked in order to enable the Nigerian public services, most especially Ondo States Civil Service address challenges inherent in the implementation of public procurement policy. One key influence on the implementation of the policy in Ondo State is Non-familiarisation of officers connected with policy implementation with the extant rules. This should be addressed urgently. Public procurement officers should endeavour to study their manuals and get familiar with the rules guiding procurement. Public procurement rules should be adequately applied by relevant professionals in the civil service and the loopholes in Ondo State procurement policy that provides room for corrupt practices which increase contract cost should be blocked with appropriate legislation that will eliminate incentive for corruption in the system.

\section{References}

Akpan-Obong, P. (2010). Unintended Outcomes in Information and Communication Technology Adoption: A Micro-Level Analysis of Usage in Context. Journal of Asian and African Studies. https://doi.org/10.1177/0021909609357412

Anderson, R. D., \& Kovacic, W. E. (2009). Competition Policy and International Trade Liberalisation: Essential Complements to Ensure Good Performance in Public Procurement Markets. Public Procurement Law Review Issue, (18).

Arrowsmith, S., \& Kunzlik, P. (2009). Social and Environmental Policies in EC Procurement Law. Cambridge: 
Cambridge University Press. https://doi.org/10.1017/CBO9780511576041

Arrowsmith, S., Linarelli, J., \& Wallace, D. (2000). Regulating Public Procurement: National and International Perspectives. London, UK: Kluwer Law International.

Basheka B. (2008). Public Procurement Reforms in Africa: A tool for Effective Governance of Public Sector and Poverty Reduction. In K. V. Thai (Ed.), International Hand Book of Public Procurement. Florida: CRC Press. https://doi.org/10.1201/9781420054590.ch6

Dibbie, R. (2004). Public Sector Management policies in Sub Saharan Africa. In A. K Kalu (Ed.), Agenda Setting and Public Policy in Africa. London: Ashgate Ltd.

EURODAD. (2009). Procurement and Development Effectiveness: A Literature Review. Retrieved from www.eurodad.org/uploadfiles

Fayomi, I. (2013). Public Procurement and Due Process Policy in Nigeria: Thrust Prospect and Challenges. Peak Journal of Social Sciences and Humanities, 1(4). Retrieved from http/www.peakjournal.org/sub-jouirnal-pJssuhtml

Guttman, J. (2013). Development Aid and Procurement: The Case for Reform. Global View Policy Paper 2013-05. Brokings Institution, 1775 Massachuset Ave.NW. Washington.

Hunja, R. R. (2003). Obstacles to public procurement reform in developing countries. Public Procurement: The Continuing Revolution. Kluwer Law International.

Kalu, A. K. (2004). Introduction: The Role of Ideas, Theory and Models of Public Policy in Africa. In A. K. Kalu (Ed.), Agenda for Public Sector in Africa. London: Ashgate Publishers Limited. https://doi.org/10.1515/9783110955125.1

McCrudden, C. (2007). Buying Social Justice: Equality, Government Procurement, and LegalChange. New York: Oxford University Press. https://doi.org/10.1093/acprof:oso/9780199232420.001.0001

Nash, R. J., Cibnic, J. J., Ralph, C., \& Nagle, J. F. (2006). Administration of Government Contract (4rd ed.). Washington DC: George Washington University, Walter Kluwer Law and Business.

Obasanjo, O. (2003). Nigeria from the Pond of Corruptions to Island of Integrity. Text of Lecture delivered at the $10^{\text {th }}$ Anniversary Celebration of Transparency International Berlin.

Olatunji, O. (2008). Due Process and Contractor Selection for Public Works in Nigeria. Newscastle: University of Newscastle.

Pegnato, J. A. (2008). Assessing Federal Procurement Reform: Has the Procurement Revolution Stopped? In Khi V. (Ed.), A Handbook of Public Bureau. Florida: Thai. https://doi.org/10.1201/9781420054590.ch3

Scott W. R. (2004). Institutional Theory: Encyclopaedia Theory. In C. A. Shah (Ed.), Public Sector Governance and Accountability Series. Thousand Oak: Public Service.

Thai, K. V., \& Arrowsmith, S. (Eds.). (2008). Agenda Setting and Public Policy in Africa. London: Ashgate Ltd.

Ware, G., Shaun, M., \& Edgardo, C. (2007). Corruption in Public Procurement: A perennial Challenge; In The Many Faces of Corruption. Tracking Vulnerabilities at the Sector Level. Edgardo Campos and Sanjay Pradhan, Chapter 9 p295-334.

World Bank. (2007). Challenges of African Growth: Opportunities, Constraints and strategic Directions. Washington, DC: The World Bank.

Wright, S. A. (2016). Model Procurement Policies and Practices that Deliver Maximum Value to your Organisation. City of Columbia: Purchasing Division.

\section{Copyrights}

Copyright for this article is retained by the author(s), with first publication rights granted to the journal.

This is an open-access article distributed under the terms and conditions of the Creative Commons Attribution license (http://creativecommons.org/licenses/by/4.0/). 